\title{
Hypertension prevalence among indigenous populations in Brazil: a systematic review with meta-analysis
}

\author{
Prevalência de hipertensão arterial em indígenas do Brasil: \\ uma revisão sistemática com meta-análise \\ Prevalencia de hipertensión arterial en indígenas de Brasil: \\ una revisión sistemática con meta-análisis
}

Zilmar Augusto de Souza Filho ${ }^{1,2}$, Alaidistânia Aparecida Ferreira ${ }^{1,2}$, Bernardo dos Santos ${ }^{3}$, Angela Maria Geraldo Pierin $^{3}$

${ }^{1}$ Universidade de São Paulo, Escola de Enfermagem, Programa Interunidades, PósGraduação em Enfermagem na Saúde do Adulto, São Paulo, SP, Brazil.

${ }^{2}$ Universidade Federal do Amazonas, Escola de Enfermagem, Programa Interunidades, PósGraduação em Enfermagem na Saúde do Adulto, Manaus, AM, Brazil.

${ }^{3}$ Universidade de São Paulo, Escola de Enfermagem, Departamento de Enfermagem Médico-Cirúrgica, São Paulo, SP, Brazil.

\section{ABSTRACT}

Objective: Evaluating the evidence of hypertension prevalence among indigenous populations in Brazil through a systematic review and meta-analysis. Methods: A search was performed by two reviewers, with no restriction of date or language in the databases of PubMed, LILACS, SciELO, Virtual Health Library and Capes Journal Portal. Also, a meta-regression model was designed in which the last collection year of each study was used as a moderating variable. Results: 23 articles were included in the review. No hypertension was found in indigenous populations in 10 studies, and its prevalence was increasing and varied, reaching levels of up to $29.7 \%$. Combined hypertension prevalence in Indigenous from the period of 1970 to 2014 was $6.2 \%$ (95\% CI, 3.1\% - 10.3\%). In the regression, the value of the odds ratio was 1.12 (95\% CI, $1.07-1.18$; p <0.0001), indicating a $12 \%$ increase every year in the probability of an indigenous person presenting hypertension. Conclusion: There has been a constant increase in prevalence despite the absence of hypertension in about half of the studies, probably due to changes in cultural, economic and lifestyle habits, resulting from indigenous interaction with non-indigenous society.

\section{DESCRIPTORS}

Hypertension; Indigenous Population; Prevalence; Review.

\section{Corresponding author:}




\section{INTRODUCTION}

Transformations of the modern world through the process of industrialization and urbanization led to changes in lifestyle, culture, rural exodus and the rise of chronic noncommunicable diseases, among them being cardiovascular diseases ${ }^{(1)}$. These impacts were also noticeable in Brazilian indigenous populations, driven by changes in socio-cultural, economic and lifestyle habits resulting from Indian interaction with non-indigenous society. In addition, the destruction of ecosystems located on indigenous lands or surroundings also interferes significantly in many aspects of daily life of indigenous peoples, modifying their health profile, making them more vulnerable and contributing to the increase in chronic diseases ${ }^{(2-3)}$. Nowadays, cardiovascular diseases are considered the leading cause of morbidity and mortality of individuals in the world, in developed countries and in developing countries, accounting for approximately $30 \%$ of all deaths in the world and $80 \%$ of deaths in underdeveloped countries ${ }^{(4)}$.

Hypertension stands out in this context as a major public health problem, as it is one of the major risk factors for cardiovascular disease $\mathrm{e}^{(5)}$. However, there are no studies of a national magnitude that reflect the prevalence of hypertension in Brazil. Observational Data of risk factors and protection for chronic diseases through telephone survey (VIGITEL) obtained in all state capitals and the Federal District show that the prevalence was $24.1 \%$ in $2013^{(6)}$, values below other regional studies ${ }^{(7-9)}$.

In studies conducted in the indigenous population in the 1970's and 1980's ${ }^{(10-12)}$, hypertension was virtually nonexistent. However, research conducted with an Indigenous village in Jaguapiru (Brazil, MS) in 2011 showed hypertension prevalence of $29.7 \%$ among all participating subjects and $67.5 \%$ among diabetics and individuals with impaired glucose tolerance. It was also found that $4.5 \%$ had diabetes mellitus, $2.2 \%$ had glucose intolerance, and $14 \%$ of men and $30 \%$ of women were obese ${ }^{(13)}$.

Thus, it is considered that the changes in the lifestyle of Indigenous populations in Brazil combined with the adoption and incorporation of behaviors and values stimulated by the new challenges of the contemporary world have led those people into dynamic processes of disease, such as cardiovascular disease, especially from hypertension. Therefore, this study aimed to evaluate the evidence of the prevalence rates of hypertension in indigenous populations of Brazil, through a systematic review and meta-analysis.

\section{METHOD}

This is a bibliographic study, a systematic review and meta-analysis of the prevalence of hypertension among indigenous populations in Brazil.

\section{Search strategy}

In order to construct a database of articles published on cardiovascular risk factors in indigenous populations of Brazil, searches were carried out between August and October 2014 in the following electronic data sources: National
Center for Biotechnology Information (NCBI/PubMed), Virtual Health Library (VHL), Scientific Electronic Library Online (SciELO), Latin American and Caribbean Health Sciences Literature (LILACS) and in Capes Journal Portal. The descriptors available in Health Sciences Descriptors (DeCS) were used.

There was no date, sample size or language restrictions for assessing publications, however, the selected publications were only in Portuguese and English. PRISMA protocol $^{(14)}$ was used as a guide for the systematic review. Considering hypertension as one of the main risk factors of cardiovascular disease, the terms used for the search were: "fator de risco cardiovascular," "hipertensão/hypertension," "pressão arterial/blood pressure," "diabetes" "obesidade/obesity," "síndrome metabólica/metabolic syndrome," using the Boolean terms "and" to include terms "índios," "indígena/ indigenous" in the search fields "search," "assunto" and "palavras do título," without restriction of the publication period, but including only those whose data were collected from indigenous populations residing in Brazil. The references in the articles identified by the search strategy were also consulted and searched manually in order to summarize the work and literature review.

\section{INCLUSION AND EXCLUSION CRITERIA}

Inclusion criteria were: original exploratory studies using quantitative methodology on indigenous people, from any ethnicity or village of Brazil, without age restriction, and whose results presented data on the prevalence of hypertension. Exclusion criteria were: studies investigating other cardiovascular risk factors in isolation, such as diabetes mellitus, obesity, dyslipidemia and sedentary lifestyle among Indigenous peoples; studies involving only a description of anthropometric data, body mass index, nutritional and metabolic profiles; cancer screening studies among indigenous people; letters, notes, abstracts, dissertations, theses, duplicate articles, monography and case studies.

\section{IDENTIFICATION, STUDY SELECTION AND DATA EXTRACTION}

Two evaluators separately read the titles and abstracts of each pre-selected reference in order to identify only the studies that properly met the inclusion criteria. This was followed by reading the articles separately, in order to ensure the criteria of the systematic review. In case of disagreement between the two reviewers, a third party evaluated the manuscript, and by consensus, a decision was made for inclusion. Manuscripts were evaluated with the instrument Strengthening the Reporting of Observational Studies in Epidemiology Statement (STROBE) ${ }^{(15)}$.

\section{DATA ANALYSIS}

Data were entered into a Microsoft Office Excel (2013) spreadsheet with essential items such as bibliographic data, title, objectives, study design, context, participants, year of data collection, variables, blood pressure measurement, diagnostic criteria for hypertension, sample size, statistical methods, main results, tables and graphs of the findings. 
For statistical analysis, data were included in a metaanalysis model of random-effects adjusted for restricted maximum likelihood. The continuity correction was used for studies with zero prevalence and applied to the logistic transformation across all data. A meta-regression model was also done, for which the last year of collection of each study was used as a moderating variable. All analyzes were performed in the statistical package R 3.1.2, and the confidence level set at $95 \%$.

\section{RESULTS}

\section{StUdy IDENTIFICATION AND SELECTION OF STUDIES}

Of the 60 references gathered by the search strategy, 43 full papers were obtained for reading. Of these, twelve studies were excluded because they conducted investigations about anthropometric, nutritional, lipid, metabolic and diabetes mellitus profiles, revealing no information about the blood pressure of the indigenous population studied. Also excluded were theses, dissertations and monographies, there were three articles published in databases which were the result of a thesis and two dissertations; these were included in this review. Finally, 23 met the proposed inclusion criteria for the systematic review and meta-analysis (Figure 1), being characterized by the year and publishing journal, the location of the study including ethnicity and village, period of data collection, number of participants, stratified participants by sex and age, blood pressure measurement and the prevalence of hypertension rates among the indigenous studied.

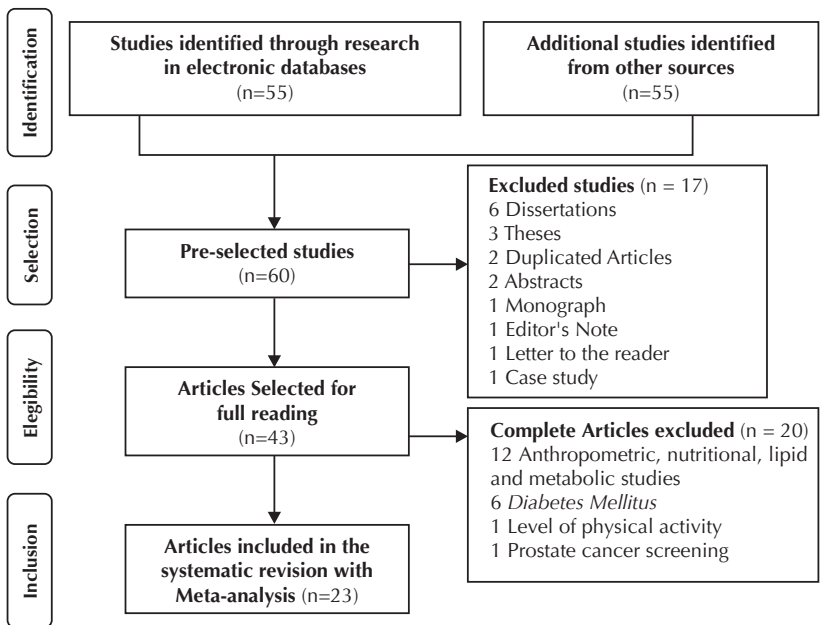

Figure 1 - Flowchart of publication selection on the prevalence of hypertension in indigenous populations of Brazil - São Paulo, SP, Brazil, 1975-2014.

\section{General Characteristics of THE Selected STUDies}

It was found that the studies on the prevalence of hypertension in indigenous populations in Brazil have been published in scientific journals since the 1970s, and they intensified from the year 2000 to the present day: there were nine publications in the period $1975-2000$ and 14 articles from 2001 to 2014 . There was a balance between national (12) and international (11) publications. There was a predominance of journals with a public health theme (9) and cardiology (8), while the rest were distributed among other health care journals (2), human biology (2) and Endocrinology and Metabolism (1).

The geographical distribution of indigenous groups studied showed that residents of the Central-West were analyzed in 10 studies (Terena, Zoró, Suyá, Kalapalo, Kuikuro, Matipu, Nahukwá, Mehináku, Waurá, Yawalapití, Guaraní, Tupinikin, Suruí, Xavantes, Khisêdjê and Jaguapiru village); another 10 publications included those conducted in northern lands (Ianomâmi, Suruí, Tembé, Amondaua, Parkatêjê, Suruí); and only two publications on ethnic groups located in the southeast and south (Guaraní-Mbyá, Kaingangs). We point out that there was only one study of broader scope that included indigenous residents in the Northeast. This study had nationwide inter-ethnic coverage, and included 113 indigenous ethnic groups: 60 located in the Northern region, 22 in the Northeast, 13 in the Central-West and 18 in the South and Southeast of Brazil.

\section{Overview of Results}

With the 23 selected articles about the prevalence of hypertension in the indigenous peoples of Brazil, it was possible to identify that no cases of hypertension were detected in 10 of them, and the others had varied prevalence, with minimal rates of $1.0 \%$ to a maximum of $29.7 \%$ (Chart 1 ).

It may be observed from the years presented in the articles as data collection periods that the indigenous people's blood pressure levels began to be measured for research purposes from the mid-1960s to 2012. Only one study ${ }^{(27)}$ did not specify the period of data collection. The age range was varied, including children and adolescents, even those with values above or equal to 69 years. Ages greater than or equal to 20 years was established as a criterion for inclusion in most studies (10). We point out that age was estimated from the indigenous phenotype and by morphological and behavioral characteristics in three studies ${ }^{(12,16,23)}$, due to lack of identification records and unawareness of their age by some of the indigenous people.

It is important to mention that three articles ${ }^{(18,24,26)}$ presented a different number of participants in the sample from those who had their blood pressure measured and presented in the results. Almost all the studies (21) were performed with both genders, except for one study ${ }^{(11)}$ that investigated only men and another ${ }^{(31)}$ that investigated only indigenous women.

As a criterion for hypertension, most studies (18) used values equal to or above $140 \mathrm{mmHg}$ and/or $90 \mathrm{mmHg}$ for systolic and diastolic blood pressure, respectively. In two studies, the cutoff point was equal to or above $160 \mathrm{mmHg}$ for the systolic and/or $95 \mathrm{mmHg}$ in diastolic blood pressure. One study ${ }^{(19)}$ evaluated hypertension compared to the two cutoff points mentioned above. It is noteworthy that one study ${ }^{(30)}$ established the largest cutoff as higher than or equal to $130 / 85 \mathrm{mmHg}$, and one study ${ }^{(10)}$ showed no diagnostic criteria. It is also noteworthy that in seven studies ${ }^{(11,23,26-28,30,33)}$, the presence of previous diagnosis of hypertension and/or treatment with antihypertensive medication were considered in addition to blood pressure levels. 
Chart 1 - Prevalence of hypertension in publications of indigenous populations in Brazil by ethnic groups/villages, data collection period and sample of participants in a systematic review - São Paulo, SP, Brazil, 1975-2014.

\begin{tabular}{|c|c|c|c|c|c|c|}
\hline \multirow{2}{*}{ Publication } & \multirow{2}{*}{ Ethnic group, Location, Villages } & \multirow{2}{*}{$\begin{array}{l}\text { Data } \\
\text { collection } \\
\text { period }\end{array}$} & \multirow{2}{*}{$\begin{array}{l}\text { Number of } \\
\text { Participants } \\
\text { (Age, years) }\end{array}$} & \multicolumn{2}{|c|}{ Gender } & \multirow{2}{*}{\begin{tabular}{|c} 
Prevalence of \\
Hypertension \\
$(\%)$
\end{tabular}} \\
\hline & & & & Men & Woman & \\
\hline $\begin{array}{l}\text { Oliver JV et al. Circulation. 1975; } \\
52: 146-151^{(10)}\end{array}$ & $\begin{array}{c}\text { Ianomâmi (RR) - (16 villages - Brazil, } \\
\text { Venezuela) }\end{array}$ & $\begin{array}{l}1966 \text { to } \\
1968\end{array}$ & $506(0-50)$ & 244 & 262 & None $^{\Psi}$ \\
\hline $\begin{array}{l}\text { Mancilha-Carvalho JJM et al. Arq Bras } \\
\text { Cardiol. 1983;40(2): } 115120^{(11)} \text {. }\end{array}$ & $\begin{array}{c}\text { Terena, Miranda and Aquidauana } \\
\text { Cities (MT) }\end{array}$ & $\begin{array}{l}1976 \text { to } \\
1978\end{array}$ & $151(20-70)$ & 151 & - & $7.2^{*}$ \\
\hline $\begin{array}{l}\text { Mancilha-Carvalho JJM et al. Arq Bras } \\
\text { Cardiol.1992;59(4):275-283(16). }\end{array}$ & $\begin{array}{l}\text { lanomâmi, Maturacá and Maiá } \\
\text { Rivers (AM), Serra do Surucucu and } \\
\text { Catrimani and Ajarani Rivers, (RR) }\end{array}$ & $\begin{array}{c}1982 \\
1985 \\
1986 \text { and } \\
1987 \\
\end{array}$ & $663(\geq 15)$ & 321 & 342 & None $^{\neq}$ \\
\hline $\begin{array}{l}\text { Mancilha-Carvalho JJ et al. Arq Bras } \\
\text { Cardiol. 1991; 56(6):477-482 }\end{array}$ & lanomâmi (RR) & 1985 & $254(>14)$ & 125 & 129 & None ${ }^{*}$ \\
\hline $\begin{array}{l}\text { Mancilha-Carvalho JJ et al. } \\
\text { Hypertension. } 1989 ; 14(3): 238-46^{(17)} \text {. }\end{array}$ & $\begin{array}{c}\text { Ianomâmi, Serra do Surucucu (RR) - } \\
\text { (10 villages) }\end{array}$ & 1986 & $195(\geq 20-59)$ & 99 & 96 & None ${ }^{*}$ \\
\hline \multirow{2}{*}{$\begin{array}{l}\text { Fleming-Moran M et al. Hum Biol. } \\
\text { 1991:63(6):835861 }\end{array}$} & Zoró, Aripuanã Indigenous Park (MT) & \multirow{2}{*}{1988} & $88(\geq 18)$ & 44 & 44 & None $^{*}$ \\
\hline & Suruí, Aripuanã Indigenous Park (RO) & & $114(\geq 18)$ & 60 & 54 & None $^{*}$ \\
\hline $\begin{array}{l}\text { Bloch KV et al. Cad. Saude Publica. } \\
\text { 1993;9(4):428-438 }\end{array}$ & lanomâmi, Serra do Surucucu (RR) & 1992 & $51(\geq 18)$ & 29 & 22 & None $^{\#}$ \\
\hline $\begin{array}{l}\text { Nascimento JRL et al. Rev Para Med. } \\
\text { 1998;12(3):4548(20). }\end{array}$ & $\begin{array}{c}\text { Tembé - (03 Turé-Mariquita, Acará- } \\
\text { Mirim and Urumateua Villages - } \\
\text { Tomé-Açú City, (PA) }\end{array}$ & 1997 & $23(\geq 18)$ & 12 & 11 & None $^{¥}$ \\
\hline $\begin{array}{l}\text { Pavan L et al. J Hypertens. } \\
1999,17: 749-756^{(21)} \text {. }\end{array}$ & Amondaua (RO) & 1997 & $30(15-58)$ & 13 & 17 & None $^{¥}$ \\
\hline $\begin{array}{l}\text { Salvo VLMA et al. Rev Bras } \\
\text { Epidemiol. 2009, 12(3):458-68 }{ }^{(22)} \text {. }\end{array}$ & $\begin{array}{l}\text { Suyá, Xingu Indigenous Park (Médio } \\
\text { Rio Xingu) (MT) }\end{array}$ & 1999 & $86(\geq 20)$ & 45 & 41 & $4.65^{¥}$ \\
\hline Cardoso AM et al. Cad. Saude & Guaraní Mbyá (RJ) & 2000 & $145(\geq 15+50)$ & 77 & 68 & $4.8^{¥}$ \\
\hline \multirow{4}{*}{$\begin{array}{l}\text { Gimeno SGA et al. J Epidemiol } \\
\text { Community Health. 2009;63:299- } \\
\text { 304 } 4^{(24)} \text {. }\end{array}$} & Kalapalo, Xingu Indigenous Park (MT) & \multirow{4}{*}{$\begin{array}{l}2000 \text { and } \\
2003\end{array}$} & $95(\geq 20)$ & 53 & 42 & None $^{*}$ \\
\hline & Kuikuro, Xingu Indigenous Park (MT) & & $116(\geq 20)$ & 54 & 62 & $5.6^{*}$ \\
\hline & Matipu Xingu Indigenous Park (MT) & & $13(\geq 20)$ & 5 & 8 & None $^{*}$ \\
\hline & $\begin{array}{c}\text { Nahukwá, Xingu Indigenous Park } \\
\text { (MT) }\end{array}$ & & $27(\geq 20)$ & 13 & 14 & $15.4^{¥}$ \\
\hline $\begin{array}{l}\text { Gimeno SGA et al. Cad. Saude } \\
\text { Publica. 2007;23(8):1946-1954(25). }\end{array}$ & $\begin{array}{c}\text { Mehináku, Waurá and Yawalapití, } \\
\text { Xingu River (MT) }\end{array}$ & $\begin{array}{l}2000 \text { to } \\
2002\end{array}$ & $201(\geq 20)$ & 102 & 99 & $7.6^{*}$ \\
\hline $\begin{array}{l}\text { Tavares EF et al. Arq Bras Endocrinol } \\
\text { Metab. 2002; 46(3);260-268 }\end{array}$ & $\begin{array}{c}\text { Parkatêjê, Indigenous area Mãe } \\
\text { Maria, Bom Jesus City, Tocantins, (PA) } \\
\end{array}$ & 2002 & $90(\geq 20)$ & 56 & 34 & $4.4^{*}$ \\
\hline \multirow{2}{*}{$\begin{array}{l}\text { Mancilha-Carvalho JJ; Silva NAS. Arq } \\
\text { Bras Cardiol. 2003; 80(3):295-300 }\end{array}$} & lanomâmi (RR) & \multirow{2}{*}{$\begin{array}{c}\text { Not } \\
\text { specified }\end{array}$} & $25(25-59)$ & \multicolumn{2}{|c|}{ Not specified } & None $^{*}$ \\
\hline & Xingu Indigenous Park (MT) & & $25(25-59)$ & \multicolumn{2}{|c|}{ Not specified } & $1.0^{*}$ \\
\hline \multirow{2}{*}{$\begin{array}{l}\text { Meyerfreund D et al. J Hypertens. } \\
\text { 2009; } 27(9): 1753-1760^{(28)} \text {. }\end{array}$} & $\begin{array}{c}\text { Guaraní, Aracruz Indigenous Reserve } \\
\text { (MT) }\end{array}$ & \multirow{2}{*}{$\begin{array}{l}2003 \text { and } \\
2004\end{array}$} & $60(\geq 20)$ & 24 & 36 & $1.5^{*}$ \\
\hline & $\begin{array}{c}\text { Tupinikin, Aracruz Indigenous } \\
\text { Reserve (MT) }\end{array}$ & & $496(\geq 20)$ & 246 & 250 & $20.8^{¥}$ \\
\hline $\begin{array}{l}\text { Tavares FG et al. Cien Saude Colet, } \\
\text { 2013;18(5):1399-1409 } 29 \text {. }\end{array}$ & $\begin{array}{l}\text { Suruí, Sete de Setembro Indigenous } \\
\text { Land (RO and MT) - (11 villages) }\end{array}$ & 2005 & $251(>20)$ & 124 & 127 & $2,8^{*}$ \\
\hline $\begin{array}{l}\text { Oliveira GF et al. Rev Panam Salud } \\
\text { Publica. 2011; 29(5):315-321 (13) }\end{array}$ & Jaguapiru Village, Dourados City (MS) & $\begin{array}{l}2007 \text { to } \\
2008\end{array}$ & $606(18-69)$ & 268 & 338 & $29.7 \% *$ \\
\hline $\begin{array}{l}\text { Anjos HNK et al. Braz arch biol } \\
\text { technol. } 2011 ; 54(1): 81-89^{(30)} \text {. }\end{array}$ & $\begin{array}{l}\text { Kaingangs, Terra indígena Faxinal, } \\
\text { Cândido de Abreu City (PR) }\end{array}$ & 2008 & $82(\geq 15)$ & 49 & 33 & $26.8^{\S}$ \\
\hline $\begin{array}{l}\text { Coimbra Jr CEA et al. BMC Public He } \\
\text { alth.2013;13(52):1471-1490(31) }\end{array}$ & $\begin{array}{c}\text { Interethnicity study/123 North, } \\
\text { northeast, central-west, southeast and } \\
\text { south region villages (BR) }\end{array}$ & $\begin{array}{l}2008 \text { to } \\
2009\end{array}$ & $6.692(15-49)$ & - & 6.692 & $13.2^{¥}$ \\
\hline \multirow{2}{*}{$\begin{array}{l}\text { Dal Fabbro AL et al. Ethn Dis. 2014; } \\
24: 35-40^{(32)} \text {. }\end{array}$} & \begin{tabular}{|c|} 
Xavantes/ Sangradouro Volta Grande \\
village (MT)
\end{tabular} & \multirow{2}{*}{$\begin{array}{l}2008 \text { to } \\
2012\end{array}$} & $318(\geq 20)$ & 162 & 156 & $17.5^{¥}$ \\
\hline & Xavantes/São Marcos Village (MT) & & $630(\geq 20)$ & 301 & 329 & $17.2^{¥}$ \\
\hline $\begin{array}{l}\text { Oliveira GF et al. PLoSOne.2014;9(1) } \\
\text { :e86278-284(33). }\end{array}$ & Jaguapiru Village, Dourados City (MS) & $\begin{array}{l}2009 \text { to } \\
2011\end{array}$ & $1.608(\geq 18)$ & 729 & 879 & $29.5^{¥}$ \\
\hline $\begin{array}{l}\text { Santos KM et al. Cad. de Saude } \\
\text { Publica. } 2012 ; 28(12): 2327-38^{(34) .}\end{array}$ & Khisêdjê, Xingu Indigenous Park (MT) & $\begin{array}{l}2010 \text { and } \\
2011\end{array}$ & $170(\geq 20)$ & 102 & 68 & $6.8^{¥}$ \\
\hline
\end{tabular}

$\Psi$ No known cutoff established for the diagnosis of hypertension

\# Cutoff point for hypertension diagnosis $\geq 160 \mathrm{mmHg}$ (SBP) and/or $\geq 95 \mathrm{mmHg}$ (DBP)

$¥$ Cutoff point for hypertension diagnosis $\geq 140 \mathrm{mmHg}$ (SBP) and/or $\geq 90 \mathrm{mmHg}$ (DBP)

$\S$ Cutoff point for hypertension diagnosis $\geq 130 \mathrm{mmHg}$ (SBP) and/or $\geq 85 \mathrm{mmHg}$ (DBP)

$\mathrm{SBP}=$ Systolic blood pressure

$\mathrm{DBP}=$ Diastolic blood pressure 
Regarding the blood pressure measurement procedures in the evaluated studies, the auscultation technique was the most used (19), using mercury sphygmomanometer (08), aneroid devices (05), Random-Zero (04), and two used both mercury sphygmomanometer as well as the aneroid. Automated instruments with the oscillometric technique were used in four studies. Only three studies mentioned the calibration gauge.

The sitting position was the most used and mentioned in performing blood pressure measurements in the majority of studies (20), as well as making reference to the time interval between the two or three measurements (19). Previous processes leading up to the measurements were seldom mentioned; these were: emptying bladder (02) and rest (03), and less than half indicated who performed the measurement. Among them were members of the nursing team (06), doctors (03) and indigenous health agents (03) (Chart 2).

Chart 2 - Blood pressure measurement criteria in publications with indigenous population in Brazil - São Paulo, SP, Brazil, $1975-2014$.

\begin{tabular}{|c|c|}
\hline Measurement criteria & $\begin{array}{l}\text { Number of Publications } \\
N \text { (ref) }\end{array}$ \\
\hline \multicolumn{2}{|l|}{ Equipment used for measurements } \\
\hline Mercury column & $08^{(11-12,18,21-22,24,29,30)}$ \\
\hline Aneroid & $05^{(13,19-20,26,33)}$ \\
\hline Mercury column and/ or Aneroid & $02^{(10,25)}$ \\
\hline Random-Zero & $04^{(1-17,23,27)}$ \\
\hline Semi-automatic & $04^{(28,31-32,34)}$ \\
\hline \multicolumn{2}{|c|}{ Procedures prior measuring blood pressure } \\
\hline Resting before measurement & $03^{(17,27,33)}$ \\
\hline Emptying bladder & $02^{(17,27)}$ \\
\hline Not specified & 18 \\
\hline \multicolumn{2}{|c|}{ Positioning for blood pressure measurement } \\
\hline Supine position & $01^{(10)}$ \\
\hline Sitting with feet flat on the floor & $21^{(11-13,16-22,24-29,30-34)}$ \\
\hline Not specified & $01^{(23)}$ \\
\hline \multicolumn{2}{|l|}{ Number of measurements made } \\
\hline Two & $19^{(11-13,16-27,29,30-31,33)}$ \\
\hline Three & $03^{(28,32,34)}$ \\
\hline Not specified & $01^{(10)}$ \\
\hline \multicolumn{2}{|l|}{ Interval between measurements } \\
\hline Up to 05 minutes & $06^{(12,17,20-21,30,33)}$ \\
\hline 05 to 10 minutes & $06^{(11,16,18,28-29,31)}$ \\
\hline 10 to 15 minutes & $07^{(13,19,22,24,26,31,34)}$ \\
\hline Not specified & $04^{(10,23,25,27)}$ \\
\hline \multicolumn{2}{|c|}{ Responsible for blood pressure measurements } \\
\hline Nursing staff & $06^{(11,16,22,25,31,34)}$ \\
\hline Doctor & $03^{(11,21,34)}$ \\
\hline Indigenous Health Agent & $03^{(22,25,31)}$ \\
\hline Other health professionals & $03^{(16,31,34)}$ \\
\hline Students of health sciences & $01^{(11)}$ \\
\hline
\end{tabular}

Figure 2 presents evidence from the meta-analysis that combines the prevalence of hypertension of 13,811 indigenous people, selected from different ethnic groups and villages in the Brazilian national territory. With regards to the number of participants from indigenous studies, it is highlighted that 18 studies assessed blood pressure levels of all indigenous present for the data collection. In five studies, the number of indigenous participants was defined by sample calculation.

It was found in the studies that the absence of hypertension in Brazilian Indigenous people became evident from the 1970s, and this phenomenon was still found in 
publications of the decades following (1980-1990). However, it is noteworthy that in the 1990s there were twice as many published studies (6) on hypertension in indigenous populations in Brazil when compared to previous decades (3). Also noteworthy during this period was that only one indigenous group in Brazil, Terena (MT), presented hypertension with a prevalence of $7.2 \%$. From the year the 2000, it can be seen that there has been an increase in hypertension.

Data presented in Figure 2 show wide variation in the prevalence rates of hypertension in the five decades included in the meta-analysis. In the 1970s, hypertension among indigenous populations was virtually non-existent: $0.1 \%(95 \%$ $\mathrm{CI}=0.0 \%-0.6 \%)$. In the following period in 1983, there was an increase to $7.3 \%(95 \% \mathrm{CI}=3.7 \%-12.0 \%)$, although a study at the end of the decade (1989) pointed to lower levels: $0.3 \%$ (95\% CI $=0.0 \%-1.4 \%)$. In the 1990 s, no studies found hypertension in indigenous populations, so the higher estimates were 1.6\% (95\% CI $=0.0 \%-8.9 \%)$ and $2.1 \%(95 \% \mathrm{CI}=0.0 \%-11.4 \%)$. In the 2000 s, the results of the meta-analysis showed variations of $2.0 \%(95 \% \mathrm{CI}=$ $0.0 \%-7.7 \%)$ up to $16.3 \%(95 \% \mathrm{CI}=12.0-21.2 \%)$. However, it was between 2011 and 2014 that the largest estimate was observed: $29.7 \%$ ( $95 \%$ CI $=26.1 \%-33.4 \%$ ), showing evidence of the presence and the increased prevalence of hypertension. From the 16 indigenous ethnic groups studied, only three showed no hypertension during this period.

Publication

Estimate $[95 \% \mathrm{Cl}]$

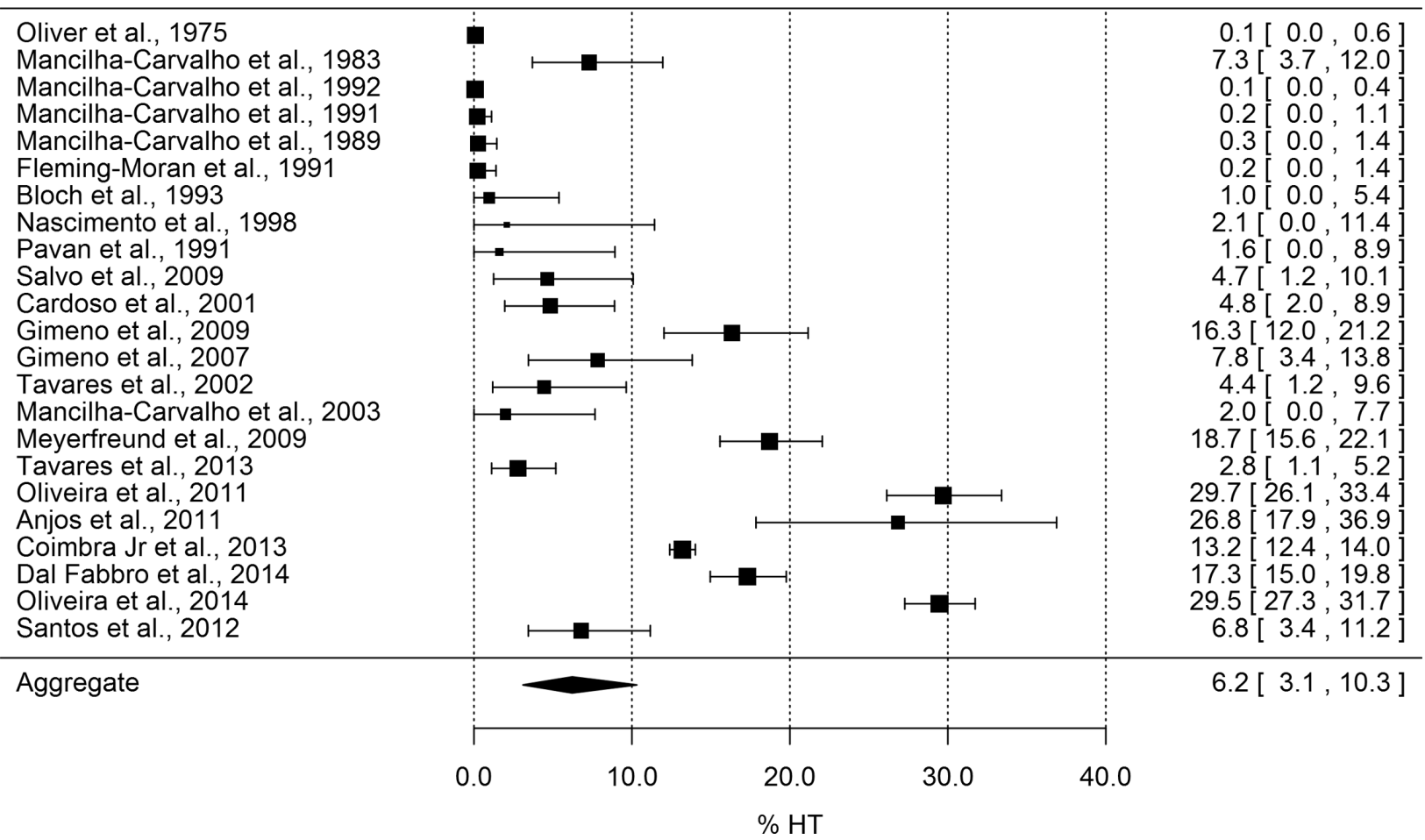

Figure 2 - Forest plot of hypertension prevalence in indigenous populations of Brazil - São Paulo, SP, Brazil, $1975-2014$.

In the data presented in Table 1 , the results of the meta-regression model were calculated from the final year of collection of assessed each study. It can be observed that there has been increasing prevalence of hypertension in indigenous populations, from a virtually non-existent value (0.2\%) up to rates of $19.2 \%$.
The odds ratio (OR) adjusted for each year collection of studies was 1.12 (95\% CI $=1.07-1.18$; $\mathrm{p}<0.0001)$, indicating a $12 \%$ increase in the probability of occurrence of hypertension in an Indigenous person in Brazil, for each year studied.

Table 1 - Meta-regression model according to the last year of data collection for each study - São Paulo, SP, Brazil, 1975-2014.

\begin{tabular}{lccc}
\hline Year of data collection & Hypertension Prevalence (\%) & Confidence Interval (lower \%) & Confidence Interval (upper \%) \\
\hline 1968 & 0.2 & 0.0 & 0.9 \\
1978 & 0.5 & 0.2 & 1.7 \\
1985 & 1.1 & 0.4 & 2.7 \\
1986 & 1.2 & 0.5 & 2.9 \\
1987 & 1.4 & 0.6 & 3.2 \\
1988 & 1.5 & 0.7 & 3.4 \\
1992 & 2.4 & 1.2 & 4.6 \\
\hline
\end{tabular}




\begin{tabular}{lccc}
\hline Year of data collection & Hypertension Prevalence (\%) & Confidence Interval (lower \%) & Confidence Interval (upper \%) \\
\hline 1997 & 4.2 & 2.5 & 6.9 \\
1999 & 5.2 & 3.1 & 8.3 \\
2000 & 5.7 & 3.5 & 9.2 \\
2002 & 7.1 & 4.4 & 11.3 \\
2003 & 7.9 & 4.9 & 12.5 \\
2004 & 8.7 & 5.4 & 13.9 \\
2005 & 9.7 & 5.9 & 15.6 \\
2008 & 13.1 & 7.6 & 21.7 \\
2009 & 14.5 & 8.2 & 24.2 \\
2011 & 17.5 & 9.5 & 29.9 \\
2012 & 19.2 & 10.2 & 33.1
\end{tabular}

OR (odds ratio) $=1.12 ; 95 \% \mathrm{Cl}$ (Confidence Interval $)=1.067-1.18, \mathrm{p}<0.0001$.

\section{DISCUSSION}

In this study, the main finding showed that the combined prevalence of hypertension among Indigenous people in the period 1970-2014 was 6.2\%, and in the regression analysis the odds ratio was 1.12 . Therefore, there was a $12 \%$ increase in the possibility of a Brazilian indigenous person showing hypertension for each year of the study period. Mortality rates from infectious and parasitic diseases in Brazil were high, and were higher than those of non-communicable and chronic cardiovascular diseases for the general population; the health of Brazilian indigenous people also suffered consequences of the transformations that have occurred in the health-disease process ${ }^{(1)}$. Infectious and parasitic diseases were and still are a major contributing factor to the increase in morbidity and mortality rates in Brazil. With the process of epidemiological transition, chronic and cardiovascular diseases and external causes of illness and death began to exert strong pressure on the disease and death profiles among indigenous populations in the country ${ }^{(2)}$. In this manner, some epidemiological studies ${ }^{(25,29,34)}$ began to reveal the increase in cases of chronic diseases in various indigenous peoples of Brazil. In this sense, they have attributed the possible causes of increased hypertension to a change in habits and lifestyles due to the Westernization that has been adopted by the indigenous population.

In the present review, initially hypertension was not present in indigenous people in Brazil, as revealed in almost half of the studies. However, the prevalence has been increasing and varied, reaching levels of up to $29.7 \%$. This result approaches the study findings where the prevalence of hypertension in non-indigenous populations from 72 Brazilian cities of five regions of the country was $28.5 \%{ }^{(35)}$. However, compared to VIGITEL results in 2013, the prevalence of hypertension in indigenous people was slightly higher than what was referred to in this review $(24.1 \%)^{(6)}$. A systematic review and meta-analysis in the general Brazilian population showed a decrease in hypertension rates in national publications between the periods 1980,1990 and 2000 , whose findings were $36.1 \%, 32.9 \%$ and $28.7 \%$, respectively $(\mathrm{p}<0.001)^{(36)}$.
In Brazil, a study ${ }^{(16)}$ conducted in the northern region with the Ianomâmi indigenous, an ethnic group separate from an urban area, considered that the lifestyle, food, and cultural habits when not westernized have a low risk of cardiovascular disease and chronic diseases.

The diet in this context has been widely discussed and emphasized in the transformation process of indigenous life, highlighting the nutritional transition experienced by indigenous populations arising from changes in their lifestyles. Studies ${ }^{(13,29,30,31,34)}$ that address this transition have pointed out that the blood pressure levels of indigenous changed after the consumption of high amounts of sodium, vegetable oil, sugar, processed and high-calorie foods, tobacco and alcoholic beverages. This scenario was also approached in other studies ${ }^{(10-12,16-17,19,27)}$ carried out with the Ianomâmi ethnic group, in which an increase in blood pressure was not identified, noting that they had a low intake of sodium, potassium, and fiber, and they performed physical activity regularly. These actions when maintained can contribute to preventing the disease process of cardiovascular disease, especially high blood pressure/hypertension.

The first publication ${ }^{(10)}$ which was part of this review is a pioneer study in the field, proving the direct relationship between blood pressure levels, hormonal levels and the amount of sodium present in the diet of Ianomâmi Indigenous. These indigenous people live in villages in northern Brazil and southeastern Venezuela, virtually isolated from contact with non-indigenous people. Their food consisted mainly of boiled banana, irregularly supplemented with fish, insects and wild plant foods. Therefore, they had no access to sodium chloride at the time of data collection in seven expeditions in 1966, 1967 and 1968. The main results showed that blood pressure increased from the first to the second decade of life, but in contrast with civilized people, no systematic increase over the years of subsequent life. In evaluating the urine of indigenous male adults, the urine excretion of sodium was only 1(1.5) $\mathrm{mEq}$. Plasma renin activity was high and similar in relation to civilized individuals in short periods of diets with $10 \mathrm{mEq}$ of sodium. Likewise, aldosterone excretion rates equaled individuals accustomed to a low-sodium diet. 
The authors concluded that hormonal adjustments for low sodium intake throughout life are similar to those achieved in the acute sodium restriction in non-indigenous people. High levels of aldosterone and renin were probably the norm for most of human evolution, and suggest that the values observed in non-indigenous control groups were suppressed by excessive consumption of salt in their diet.

Also in the north region, two studies were carried out with the Suruí ethnic group, and there was an increased prevalence of hypertension in the period between 1988 and 2005. In the first study, the data collected from 114 indigenous people from the Aripuanã Indigenous land in the state of Rondônia did not detect hypertension ${ }^{(18)}$. But in the second, conducted in 2005 with 251 indigenous Suruí from eleven villages of the indigenous territory of Sete de Setembro located on the border between the states of Rondônia and Mato Grosso, the Indians showed hypertension prevalence of $2.8 \%{ }^{(26)}$. Obesity was also evident among the Suruí indigenous in $22 \%$ of women and $9.7 \%$ of men, with a significant difference between the genders $(p=0.007)$. The percentage values of changed anthropometric measurements were also higher among indigenous women than in men; waist circumference $(70.1 \%$ vs $27.4 \%$; $p$ $<0.000$ ) and waist/hip ratio ( $85 \%$ vs 54\%; $\mathrm{p}<0.000$ ). These values showed an inversion, primarily with weight measurements among the Suruí indigenous evaluated in 1988, in which men showed higher average weight than women.

It should be noted that among the analyzed publications, there were assessments that were not only restricted to hypertension. Studies ${ }^{(13,22-23,26,32-33)}$ performed with different ethnic groups such as Suyá, Guaraní, Suruí, Kaingangs, Xavante and Jaguapiru village showed that, unlike the data from the studies with the Ianomâmi, other cardiovascular risk factors were found in addition to hypertension. The studies revealed the presence of: diabetes mellitus, physical inactivity, metabolic syndrome, elevated body fat levels reflected in waist circumference, presence of overweight, obesity and dyslipidemia. Indigenous people belonging to the Jaguapiru village in the city of Dourados, MT had the highest rates of hypertension. In a publication from $2014^{(33)}$, 1608 Indigenous people were evaluated and the prevalence was $29.5 \%$, and in $2011^{(13)}$ it was $29.7 \%$. Smoking (18.9\%) and the presence of unfavorable socioeconomic factors such as $64.6 \%$ with a monthly household income less than one minimum wage at the time (US\$200.17) were also found, and $12.5 \%$ were illiterate ${ }^{(13)}$. Thus, it can be assumed that these Indigenous people have adopted the way of life of non-indigenous populations, which can be justified by the urban location of their homes. In the 2014 study, among the Indigenous people who had a previous diagnosis of hypertension, only $19 \%$ had controlled blood pressure ${ }^{(33)}$. This is extremely important data considering these people are prone to complications of diseases that damage target organs with the possibility of stroke, acute myocardial infarction and kidney damage.

In the Southeast of Brazil, in a 2008 study of the indigenous Kaingangs ethnicity in the city of Cândido de Abreu of the Faxinal land in the state of Paraná, the hypertension prevalence found was also high $(26.8 \%)^{(30)}$. It is noteworthy that the main objective in this study was to evaluate the metabolic syndrome, in which the recommended cutoffs for evaluating blood pressure are lower. Thus, the values used were 130 $\mathrm{mmHg}$ for systolic pressure and/or $85 \mathrm{mmHg}$ for diastolic pressure, which may explain the higher prevalence found. Still in the Southeast region, the lowest prevalence found was in a study in the state of Rio de Janeiro in the indigenous Guaraní ethnic group from the villages of Sapukai, Paraty-Mirim and Araponga, in 2000, with 4.8\% hypertension ${ }^{(23)}$.

In the Midwest region, in addition to the study that identified the highest rate of hypertension as previously discussed, data collected between 2008 and 2012 revealed intermediate rates in the range of $17.2 \%^{(32)}$ to $20.8 \%{ }^{(28)}$. In the only study not regionalized in covering the different regions of the country, the prevalence of hypertension was slightly lower $(13.2 \%)^{(31)}$, but the primary objective in this study was to only identify hypertension in women, which might have contributed to the lower rate of hypertension.

With regards to the blood pressure measurement procedure adopted in the assessed publications, some aspects are worth mentioning. Among the studies using the auscultation technique, only three made reference to the calibration of the sphygmomanometer, and other studies ${ }^{(37-38)}$ have shown that aneroid devices tend to decalibrate easily. As for automated instruments with oscillometric technique, only those that have been validated according to specific protocol of recommendations can be used ${ }^{(39)}$. The care of the participants before the pressure measurement were also very little cited, such as having an empty bladder, not having practiced any physical activity, drunk alcohol, coffee, or smoked. However, more than one blood pressure measurement being performed as recommended by the guidelines ${ }^{(5)}$ was adopted by most studies. Regarding hypertension diagnostic criteria, the cutoff point for hypertension at $140 \mathrm{mmHg}$ for systolic pressure and/or $90 \mathrm{mmHg}$ for diastolic pressure was the most used in accordance with current recommendations, as with the current Brazilian guidelines ${ }^{(5)}$. Only three studies used $160 / 95 \mathrm{mmHg}$, the former criterion of the World Health Organization ${ }^{(40)}$, probably due to previous recommendations at the time of the studies ${ }^{(11)}$ whose data were collected between 1976-1978 from the Terena Indians in the city of Miranda and Aquidauana (MT). The other two studies $^{(18-19)}$ also adopted this criterion for higher blood pressure levels, and hypertension was non-existent, revealing that if the current cutoff points, which are lower, had been applied, the result would not have been different.

The main limitation of this study relates to the universe of the indigenous population in Brazil that was studied, resulting in the evaluation of different ethnic groups and a diversity of indigenous communities in different regions and at different stages of assimilation to culture, and probably with varied epidemiological profiles. Another finding was that the distribution of the samples was not homogeneous, especially among the variables of age and gender; this was perhaps due to the fact that it was easier to recruit women and the unavailability of male participation, depending on work activities outside the tribe.

We also stress the fact that blood pressure measurement was performed at home in most studies, which can reduce 
the white coat hypertension syndrome phenomenon, which has favorable aspects because it minimizes the influence of the observer and environment in measuring blood pressure.

\section{CONCLUSION}

From the assessment of the evidence on the prevalence rates of hypertension in the indigenous peoples of Brazil, it was concluded that although the meta-analysis has shown a low aggregate value (6.2\%), and there was an absence of hypertension in 10 of 23 studies, there has been an increase of $12 \%$ every year in the chance of an indigenous person having hypertension. These findings are probably the result of cultural, habitual, economic and lifestyle changes, resulting from the interaction of the indigenous populations with non-indigenous society. The nutritional transition was the most prominent change, with increased ingestion of sodium, saturated fats, processed products and a reduction in potassium and fiber intake is a major issue for cardiovascular risk factor. Other factors are also related to high blood pressure, such as being overweight and obese, physical inactivity, diabetes mellitus and metabolic syndrome, as well as possibilities of difficult access to health services being experienced by this population. This review suggests the need for vigilance in the control and prevention of risk factors, especially in the work of nurses in primary care and indigenous health, also including the cultural universe of the Indigenous populations to promote interventions and practices related to health and disease. This study may also contribute to assist other health professionals and managers in the implementation of health policies and actions that prioritize the indigenous populations, considering their ethnic diversity, customs and behavior.

\section{RESUMO}

Objetivo: Avaliar as evidências sobre a prevalência de hipertensão arterial em indígenas brasileiros por meio de uma revisão sistemática e realização de meta-análise. Método: Realizou-se busca por dois revisores, sem restrição de data e idioma nas bases de dados PubMed, LILACS, SciELO, Biblioteca Virtual em Saúde e Portal de Periódicos da Capes. Também foi feito um modelo de meta-regressão em que o último ano de coleta de cada estudo foi utilizado como variável moderadora. Resultados: Foram incluídos 23 artigos na revisão. Houve ausência de hipertensão nos indígenas em 10 estudos e as prevalências foram crescentes e variadas, atingindo níveis de até $29,7 \%$. A prevalência combinada de hipertensão nos indígenas no período de 1970 a 2014 foi de 6,2\% (IC95\%, 3,1\% - 10,3\%). Na regressão, o valor da razão de chances foi de 1,12 (IC95\%, 1,07 - 1,18; p < 0,0001), indicando aumento de $12 \%$ a cada ano, na chance de um indígena apresentar hipertensão arterial. Conclusão: Houve aumento crescente na prevalência, apesar da ausência de hipertensão, em cerca da metade dos estudos, provavelmente decorrente de mudanças de hábitos culturais, econômicos e de estilo de vida, resultantes da interação do índio com a sociedade não indígena.

\section{DESCRITORES}

Hipertensão; População Indígena; Prevalência; Revisão.

\section{RESUMEN}

Objetivo: Evaluar las evidencias acerca de la prevalencia de hipertensión arterial en indígenas brasileños por medio de una revisión sistemática y la realización de metanaálisis. Método: Se llevó a cabo la búsqueda por dos revisores, sin restricción de fecha e idioma en las bases de datos PubMed, LILACS, SciELO, Biblioteca Virtual en Salud y Portal de Periódicos de Capes. También se hizo un modelo de metarregresión en que el último año de recolección de cada estudio fue utilizado como variable moderadora. Resultados: Fueron incluidos 23 artículos en la revisión. Hubo ausencia de hipertensión en los indígenas en 10 estudios y las prevalencias fueron crecientes y variadas, alcanzando niveles de hasta el 29,7\%. La prevalencia combinada de hipertensión en los indígenas en el período de 1970 a 2014 fue del 6,2\% (IC95\%, 3,1\% - 10,3\%). En la regresión, el valor de la razón de probabilidades fue de 1,12 (IC95\%,1,07 - 1,18; < < 0,0001), indicando un incremento del $12 \%$ cada año en la probabilidad de que un indígena presente hipertensión arterial. Conclusión: Hubo aumento creciente en la prevalencia, pese a la ausencia de hipertensión, en cerca de la mitad de los estudios, probablemente consecuente de cambios de hábitos culturales, económicos y de estilo de vida, resultantes de la interacción del indio con la sociedad no indígena.

\section{DESCRIPTORES}

Hipertensión; Población Indígena; Prevalencia; Revisión.

\section{REFERENCES}

1. Coimbra Junior CEA, Santos RV, Escobar AL. Epidemiologia e saúde dos populações indígenas no Brasil. Rio de Janeiro: Fundação Oswaldo Cruz; 2003.

2. Basta PC, Orellana JDY, Arantes R. Perfil epidemiológico dos povos indígenas no Brasil: notas sobre agravos selecionados. In: Garnelo L, Pontes AL, organizadoras. Saúde indígena: uma introdução ao tema. Brasília: Mec-Secadi; 2012. p. 60-107.

3. Moura PG, Batista LRV, Moreira EAM. População indígena: uma reflexão sobre a influência da civilização urbana no estado nutricional e na saúde bucal. Rev Nutr. 2010;23(3):459-65.

4. Go AS, Mozaffarian D, Roger VL, Benjamin EJ, Berry JD, Blaha MJ, Dai S, et al. Heart disease and strok estatistics - 2014 update: a report from the American Heart Association. Circulation. 2014;129(3):e28-e292.

5. Sociedade Brasileira de Cardiologia; Sociedade Brasileira de Hipertensão; Sociedade Brasileira de Nefrologia. VI Diretrizes Brasileiras de Hipertensão. Arq Bras Cardiol. 2010;95 (1 Supl.1):1-51.

6. Brasil. Ministério da Saúde; Secretaria de Vigilância em Saúde. Vigitel Brasil 2013: vigilância de fatores de risco e proteção para doenças crônicas por inquérito telefônico Brasília: MS; 2014.

7. Cipullo JP, Martin JF, Ciorlia LA, Godoy MR, Cação JC, Loureiro AA, et al. Prevalência e fatores de risco para hipertensão em uma população urbana brasileira. Arq Bras Cardiol. 2010;94(4):519-26. 
8. Lyra R, Silva RS, Montenegro Junior RM, Matos MV, Cézar NJ, Fernandes VO, et al. High prevalence of arterial hypertension in a Brazilian Northeast population of low education and income level, and its association with obesity and metabolic syndrome. Rev Assoc Med Bras. 2012;58(2):209-14.

9. Piccini RX, Facchini LA, Tomasi E, Siqueira FV, Silveira DSd, Thumé E, et al. Promoção, prevenção e cuidado da hipertensão arterial no Brasil. Rev Saúde Pública. 2012;46(3):543-50.

10. Oliver WJ, Cohen EL, Neel JV. Blood pressure, sodium intake, and sodium related hormones in the Yanomamo Indians, a "no-salt" culture. Circulation.1975;52(1):146-51.

11. Mancilha-Carvalho JJ, Silva NAS, Oliveira JM, Argulles E, Silva JAF. Pressão arterial e grupos sociais: estudo epidemiológico. Arq Bras Cardiol.1983;40(2):115-20.

12. Mancilha-Carvalho JJ, Silva NAS, Carvalho JV, Lima JAC. Pressão arterial em seis Aldeias Yanomami. Arq Bras Cardiol. 1991;56(6):477-82.

13. Oliveira GF, Oliveira TRR, Rodrigues FF, Corrêa LF, Ikejiri AT, Casulari LA. Prevalência de diabetes melito e tolerância à glicose diminuída nos indígenas da Aldeia Jaguapiru, Brasil. Rev Panam Salud Pública. 2011:29(5):315-21.

14. Moher D, Liberati A, Tetzlaff J, Altman DG. Preferred reporting items for systematic reviews and meta-analyses: the PRISMA statement. PLoS Med. 2009;6(7):e1000097.

15. Vandenbroucke JP, Von Elm E, Altman DG, Egger M, Pocock SJ, Gotzsche PC, et al. The Strengthening the Reporting of Observational Studies in Epidemiology (STROBE) statement: guidelines for reporting observational studies. Epidemiology. 2007;18(6):805-35.

16. Mancilha-Carvalho JJ, Carvalho JV, Lima JAC, Silva NAS. Ausência de fatores de risco de doença coronária em índios Yanomami e influência da aculturação na pressão arterial. Arq Bras Cardiol. 1992;59(4):275-83.

17. Mancilha-Carvalho JJ, Baruzzi RG, Howard PF, Poulter N, Alpers MP, Franco LJ, et al. Blood pressure in four remote populations in the INTERSALT Study. Hypertension. 1989;14(3)238-46.

18. Fleming-Moran M, Santos RV, Coimbra Junior CEA. Blood pressure levels of the Suruí and Zoró indians of the Brazilian amazon: group and sex-specific effects resulting from body composition, health status, and age. Hum Biol.1991;63(6):835-61.

19. Bloch KV, Coutinho ESF, Lôbo MSC, Oliveira JEP, Milech A. Pressão arterial, glicemia capilar e medidas antropométricas em uma população Yanomámi. Cad Saúde Publica 1993;9(4):428-38.

20. Nascimento JRL, Miranda RA, Xavier FB, Menezes RC. Hipertensão arterial em índios adultos da tribo Tembé, nordeste do Pará. Rev Para Med. 1998;12(3):45-8.

21. Pavan L, Casiglia E, Braga LMC, Winnicki M, Puato M, Pauletto PE, et al. Effects of a traditional lifestyle on the cardiovascular risk profile: the Amondava population of the Brazilian Amazon. Comparison with matched African, Italian and Polish populations. J Hypertens. 1999;17(6):749-56.

22. Salvo VLMA, Rodrigues D, Baruzzi RG, Pagliaro H, Gimeno SGA. Perfil metabólico e antropométrico dos Suyá. Parque Indígena do Xingu, Brasil Central. Rev Bras Epidemiol. 2009;12(3):458-68.

23. Cardoso AM, Mattos IE, Koifman RJ. Prevalência de fatores de risco para doenças cardiovasculares na população Guaraní-Mbyá do Estado do Rio de Janeiro. Cad Saude Publica. 2001;17(2):345-354.

24. Gimeno SGA, Rodrigues D, Canón EN, Lima EES, Schaper M, Pagliaro H, et al. Cardiovascular risk factors among Brazilian Karib indigenous peoples: Upper Xingu, Central Brazil, 2000-3. J Epidemiol Community Health. 2009;63(4):299-304.

25. Gimeno SGA, Rodrigues D, Pagliaro H, Canón EN, Lima EES, Baruzzi RG. Perfil metabólico e antropométrico de índios Aruák: Mehináku, Waurá e Yawalapití, Alto Xingu, Brasil Central, 2000/2002. Cad Saúde Pública. 2007;23(8):1946-1954.

26. Tavares EF, Vieira-Filho JPB, Andriolo A, Franco LJ. Relação da homocisteinemia com a sensibilidade à insulina e com fatores de risco cardiovascular em um grupo indígena brasileiro. Arq Bras Endocrinol Metab. 2002;46(3):260-8.

27. Mancilha-Carvalho JJ, Silva NAS. The Yanomami Indians in the INTERSALT Study. Arq Bras Cardiol. 2003;80(3):295-300.

28. Meyerfreund D, Gonçalves CP, Cunha RS, Pereira AC, Krieger JE, Mill JG. Age-dependent increase in blood pressure in two different Native American communities in Brazil. J. Hypertens. 2009;27(9):1753-60.

29. Tavares FG, Coimbra CEA, Cardoso AM. Níveis tensionais de adultos indígenas Suruí, Rondônia, Brasil. Ciên Saúde Coletiva 2013;18(5):1399-409.

30. Anjos HNK, Toledo MJO, Mota LT, Previdelli ITS, Anjos AF, Saruhashi TR, et al. Prevalence of metabolic syndrome among Kaingang Native Americans in Southern Brazil. Braz Arch Biol Technol. 2011;54(1):81-9.

31. Coimbra Junior CEA, Santos RV, Welch JR, Cardoso AM, Souza MC, Garnelo L, et al. The first national survey of indigenous people's health and nutrition in Brazil: rationale, methodology, and overview of results. BMC Public Health. 2013;13(52)1471-90.

32. Dal Fabbro AL, Franco LJ, Silva AS, Sartorelli DS, Soares LP, Franco LF, et al. High prevalence of type 2 diabetes mellitus in Xavante Indians from Mato Grosso, Brazil. Ethn Dis. 2014;24(1):35-40.

33. Oliveira GF, Oliveira TRR, Ikejiri AT, Andraus MP, Galvão TF, Silva MT, et al. Prevalence of hypertension and associated factors in an indigenous community of central Brazil: a population-based study. PLoS One. 2014;9(1):e86278.

34. Santos KM, Tsutsui MLS, Galvão PPO, Mazzucchetti L, Rodrigues D, Gimeno SGA. Grau de atividade física e síndrome metabólica: um estudo transversal com indígenas Khisêdjê do Parque Indígena do Xingu, Brasil. Cad Saúde Pública. 2012;28(12):2327-38.

35. Nascimento Neto RM, coordenador. Atlas: corações do Brasil. São Paulo: Sociedade Brasileira de Cardiologia; 2005. Dados nacionais atuais sobre a prevalência, projeções e impacto dos fatores de risco; p. 38-54.

36. Picon RV, Fuchs FD, Moreira LB, Riegel G, Fuchs SC. Trends in prevalence of hypertension in Brazil: a systematic review with meta-analysis. PLoS One. 2012; 7(10):e48255. 
37. Serafim TS, Toma GA, Gusmão JL, ColósimO FC, Stael SBES, Pierin AMG. Evaluation of the conditions of use of sphygmomanometers in hospital services. Acta Paul Enferm. 2012;25(6):940-6.

38. Tolonen H, Koponen P, Naska A, Männistö S, Broda G, Palosaari T et al. Challenges in standardization of blood pressure measurement at the population level. BMC Med Res Methodol. 2015;15(1):33-40.

39. O'Brien E, Atkins N, Stergiou G, Karpettas N, Parati G, Asmar R, et al. European society of hypertension international protocol revision 2010 for the validation of blood pressure measuring devices in adults. Blood Press Monit. 2010;15(1):23-38.

40. World Health Organization. Hypertension and coronary heart disease: classification and criteria for epidemiological studies. Geneva: WHO; 1959. (WHO Technical Reports series, 168). 